\title{
PERANCANGAN ENTERPRISE ARCHITECTURE MENGGUNAKAN ZACHMAN FRAMEWORK PADA PERUSAHAAN KONSTRUKSI
}

\author{
William Darma ${ }^{1}$, Fransiskus Adikara ${ }^{2}$ \\ ${ }^{1,2}$ Fakultas Teknologi dan Desain, Universitas Bunda Mulia \\ Jln. Lodan Raya No. 2, Jakarta, Indonesia \\ ${ }^{1}$ s31170008@student.ubm.ac.id \\ ${ }^{2}$ fadikara@admin.ubm.ac.id
}

\begin{abstract}
Abstrak
PT. Itewe Sarana Konstruksi merupakan sebuah perusahaan yang bergerak di bidang konstuksi dan bahan bangunan. Perusahaan ini memproduksi berbagai jenis perlengkapan yang pada umumnya digunakan saat proses konstruksi sedang dilakukan. Hingga saat ini, PT. Itewe Sarana Konstruksi sudah menggunakan bantuan SI/TI untuk menjalankan proses bisnis mereka, namun dalam penerapannya, SI/TI yang digunakan masih dapat dikatakan kurang dari potensi maksimal yang ada. Maka dari itu, diperlukan sebuah rancangan SI/TI yang dapat membantu proses bisnis perusahaaan yang sedang berjalan serta membantu perusahaan dalam mewujudkan visi dan misi mereka. Enterprise Architecture merupakan sebuah metode yang dapat digunakan untuk merancang, merencanakan dan mengimplementasi sebuah desain yang dapat digunakan oleh perusahaan. Terdapat beberapa jenis framework yang dapat digunakan untuk merancang enterprise architecture tersebut. Framework yang digunakan pada penulisan ini adalah Zachman Framework. Hasil dari penulisan ini merupakan sebuah blueprint aplikasi yang diharapkan dapat digunakan oleh perusahaan untuk mengembangkan bisnis mereka. Dengan adanya blueprint ini, diharapkan pengembangan SI/TI dapat sejalan dengan visi dan misi yang dijunjung oleh perusahaan. Blueprint yang dihasilkan merupakan sebuah desain bisnis proses bagi perusahaan dan aplikasi-aplikasi dalam jangka waktu dekat yang akan diimplementasikan.
\end{abstract}

Kata kunci: Zachman Framework, Enterprise Architecture, Sistem Informasi, Sistem Enterprise.

\section{PENDAhUluan}

Dengan adanya penurunan biaya signifikan dalam penerapan teknologi informasi, sistem informasi bergerak dari peranan tradisionalnya sebagai aplikasi pendukung menjadi sebuah penawaran keunggulan kompetitif yang signifikan [1]. Dengan menggunakan sistem informasi, perjalanan perusahaan akan semakin baik. Seluruh proses yang berjalan di perusahaan akan dapat berjalan dengan efektif, efisien dan ekonomis [2].

Teknologi informasi juga tidak hanya terbatas pada sistem komputerisasi yang dapat digunakan untuk memproses dan menyimpan informasi melainkan juga mencakup teknologi dan komunikasi untuk mendapatkan dan mengirim informasi tekait keperluan bisnis [3]. Kualitas sistem informasi biasanya berujung pada peningkatan kinerja dan kecepatan proses pengambilan keputusan organisasi. Selain itu, akurasi, ketepatan waktu, dan kemudahan penggunaan dari dari sistem informasi yang baru merupakan tujuan dari pengembangan sistem informasi di sebuah perusahaan. Jadi, dapat disimpulkan bahwa keuntungan yang dapat diperoleh ketika sebuah perusahaan menggunakan teknologi informasi adalah kecepatan, konsistensi, ketepatan, dan keandalan dalam operasional organisasi [4].

Karena pentingnya keberadaan arsitektur Teknologi Informasi (TI) dalam perusahaan, maka kita perlu memahami terlebih dahulu beberapa istilah terkait perusahaan yang akan menjadi studi kasus penelitian ini. Perusahaan merupakan keseluruhan keseluruahan perbuatan yang dilakukan secara terus-menerus, dengan terang-terangan dalam kedudukan tertentu, dan untuk mencari laba bagi dirinya sendiri [5] Sedangkan Perseroan Terbatas atau PT merupakan sebuah persekutuan untuk menjalankan usaha yang memiliki modal terdiri atas saham-saham gabungan, yang pemiliknya memiliki bagian sebanyak saham yang dimilikinya [6] Definisi konstruksi adalah sebuah perusahaan yang bergerak 
dalam bidang untuk melakukan upaya untuk mencapai suatu hasil dalam bentuk bangunan atau infrastruktur [7].

Studi kasus pada penelitian ini adalah PT. Itewe Sarana Konstruksi, yaitu sebuah perusahaan yang bergerak di bidang konstruksi. Perusahaan ini merupakan bagian dari grup Global Indonesia Asia Sejahtera yang merupakan perusahaan Authorized Dealer dari principle Ramset, Rockwool dan Akfix Indonesia. Perusahaan ini memiliki pusat di Springhill Office Tower Lantai 5, Jalan Benyamin Sueb Ruas D7 Blok D6 Kecamatan Pademangan, Jakarta Utara. Demi memudahkan, mendukung serta membuat PT. Itewe Sarana Konstruksi menjadi perusahaan yang kompetetif di bidangnya, maka perlu dilakukan penerapan TI untuk menghasilkan informasi yang relevan, akurat serta tepat waktu yang dapat digunakan untuk mengambil keputusan dalam berbagai skala kebutuhan [8].

Ibarat membangun rumah, diperlukan model dan rancangan terlebih dahulu sebelum rumah benar-benar dibangun. Demikian pula halnya sewaktu hendak membangun sistem informasi. Diperlukan model atau arsitektur sistem informasi sebelum sistem informasi dibangun menggunakan bahasa pemrograman. Pemodelan sistem informasi pada dasarnya ditujukan agar sistem informasi yang dibangun tepat sasaran, efektif dan efisien, sesuai dengan harapan dan tujuan dibuatnya sistem informasi. Tanpa pemodelan, proses membangung sistem informasi akan sulit dikontrol dan hasil akhir mungkin menyimpang dari tujuan semula [9].

Enterprise Architecture (EA) adalah deskripsi tentang struktur perusahaan, yang terdiri dari komponen-komponen enterprise, sifat-sifat dan hubungan di antara komponen tersebut. EA menjelaskan terminologi komposisi komponen perusahaan, hubungannya dengan lingkungan eksternal, dan prinsip-prinsip panduan untuk kebutuhan, desain dan evolusi dari suatu perusahaan [10].

EA atau dalam bahasa Indonesia dikenal dengan arsitektur enterprise juga merupakan sebuah deskripsi dari misi para pemangku kepetentingan yang di dalamnya termasuk informasi, fungsionalitas/kegunaan, lokasi organisasi dan parameter kinerja. Dalam merencanakan dan merancang sebuah arsitektur EA, diperlukan kerangka kerja (framework) yaitu sebuah cetak biru (blueprint) yang menjelaskan bagaimana elemen teknologi informasi dan manajemen informasi bekerja sama sebagai satu kesatuan [11].

Salah satu kerangka kerja yang dapat digunakan untuk merancang EA adalah Zachman Framework. Zachman Framework adalah sebuah kerangka kerja EA yang menyediakan cara formal dan sangat terstruktur untuk melihat dan mendefinisikan suatu enterprise [10]. Baseline dari Zachman Framework yaitu memperlihatkan matriks dua dimensi yang terdiri dari artifak atau elemen di kolomnya dan perspektif atau sudut pandang di setiap barisnya, semakin ke bawah maka view-nya semakin rinci dan implementatif [12].

\section{Metodologi PENELITIAN}

Berikut merupakan penjelasan dari metode penelitian yang dilakukan sebagai berikut:

1. Studi literatur: Pada awal sebelum penelitian dilakukan, penulis melakukan studi literatur yang terkait dengan perancangan Enterprise Architecture khususnya menggunakan kerangka kerja Zachman.

2. Wawancara dan observasi: Metode ini digunakan untuk mengumpulkan informasi yang berkaitan dengan data, proses dan permasalahan yang ada pada perusahaan.

3. Percancangan EA : Data yang telah diperoleh selanjutnya akan dianalisis untuk mendapatkan rancangan enterprise architecture menggunakan zachman framework dengan studi kasus PT. Itewe Sarana Konstruksi, yang dimulai dari tahapan perancangan baris planner hingga ke tahapan terakhir yaitu baris user.

4. Analisis gap: Analisis gap akan dilakukan untuk melakukan perbandingan kondisi perusahaan sebelum perancangan arsitektur enterprise dilakukan dan setelah perancangan tersebut saat nanti diterapkan.

5. Perancangan portofolio aplikasi: perancangan portofolio aplikasi dilakukan untuk memetakan aplikasi yang sudah dihasilkan dari rancangan arsitektur enterprise sebelumnya ke dalam Strategic Grid McFarlan.

6. Penarikan kesimpulan: Tahapan ini merupakan hasil dari pengumpulan data dan analisis perancangan enterprise architecture menggunakan zachman framework dengan studi kasus PT. Itewe Sarana Konstruksi

\section{A. Latar Belakang Perusahaan}

PT. ITEWE Sarana Konstruksi berdiri tahun 2009 di Jakarta, dengan bisnis utama mendistribusikan material konstruksi dengan merek Ramset. Ramset sendiri adalah merek terkemuka dari Australia yang sudah lebih dari 60 tahun berkecimpung di dalam industri ini. PT. ITEWE Sarana Konstruksi adalah anak perusahaan dari Induk Global Group yang juga membawahi PT. Global Indonesia Asia Sejahtera sebagai perusahaan distribusi bahan bangunan dengan 32 cabang di seluruh Indonesia, PT. Bumi Lancang Kuning Perkasa, perusahaan manufacturing produk metal dan PVC dengan 6 pabrik di seluruh Indonesia, dan PT. Sobute Indonesia, perusahaan joint venture dengan China, sebagai penyedia bahan-bahan kimia konstruksi.

Dengan berjalannya waktu, PT. ITEWE Sarana Konstruksi terus berkembang melengkapi jajaran produk dengan menambahkan produk Rockwool dan brand ITEWE sendiri untuk jajaran produk sealant dan BoSET alat kerja konstruksi. Penelitian ini menggunakan studi kasus PT. ITEWE Sarana Konstruksi karena pihak perusahaan ingin mempunyai sebuah rancangan enterprise.

Visi dari perusahaan yaitu menjadi perusahaan dengan brand \& service yang menjadi pilihan pelaku dunia konstruksi, 
dan berkontribusi secara aktif dan masif dalam merancang dan membangun proyek-proyek terbaik dan terbesar di Indonesia. Sedangkan Misi perusahaan yaitu menyediakan dan terus berinovasi dalam mengembangkan produk dan sistem konstruksi, sejalan dengan sumber daya manusia yang andal, mulai dari keahlian teknis konstruksi hingga kejelasan administrasi yang menjamin ketersediaan solusi konstuksi terbaik hingga kelancaran pengadaan produk sampai di ujung penyelesaian konstruksi proyek, bahkan masa pemeliharaan dan operasi proyek sekalipun.

\section{B. Value Chain}

Bagian ini akan membahas tentang hasil pemetaan proses bisnis yang berjalan. Berikut ini merupakan hasil dari pemetaan proses bisnis yang berjalan dengan analisis Value Chain sebagai berikut:

\section{1) Aktivitas Utama:}

1. Inbound Logistic, pembelian barang dari supplier, pengirman barang yang dibeli dari supplier ke perusahaan dan penyimpanan barang di gudang perusahan.

2. Operation, proses penawaran barang ke pelanggan, pengecekan ketersediaan barang, pembuatan purchase order, penentuan term of payment, pembuatan surat jalan, pemuatan barang ke mobil box, dan penagihan.

3. Outbound Logistic, pengiriman barang ke pelanggan dan pengirman surat jalan ke pelanggan untuk ditanda tangani, dan pemberian tagihan.

4. Marketing and Penjualan, marketing dilakukan lewat email, aplikasi pesan instan Whatsapp, penawaran langsung dan rekomendasi.

5. Services, layanan yang ditawarakan perusahaan yaitu menjamin kualitas barang yang dijual ke pelanggan, pemberian garansi barang sampai ke tujuan, dan kemampuan untuk menjelaskan keguanan dari masingmasing produk yang dijual.

\section{2) Aktivitas Pendukung}

1. Firm Infrastructure, terdiri dari manajemen dalam berbagai bidang pendukung bisnis, seperti gudang penyimpanan barang, dan tempat yang dijadikan kantor oleh perusahaan.

2. Human Resource Management, proses perekrutan, seleksi dan penempatan pegawai, program bonus dan sanksi serta penggajian karyawan yang bekerja pada perusahaan.

3. Technology Development, penggunaan aplikasi accurate, Microsoft Office untuk pembuatan dokumen, e-mail, telepon dan situs web yang masih dalam tahap pengembangan.

4. Procurement, mobil box, gudang, komputer dan alat tulis kantor serta alat pendukung kantor lainnya seperti meja, kursi dan lain-lain.

\section{Analisis SWOT}

Tabel 2 menunjukkan hasil analisis SWOT pada perusahaan saat ini.

Setelah dilakukan penilaian dan pertimbangan terhadap aktivitas bisnis dan kelebihan dan kekurangan yang dimiliki oleh perusahaan melalui analisis value chain dan analisis SWOT, maka dapat dihasilkan beberapa kandidat aplikasi yang akan diusulkan bagi perusahaan. Tabel 1 akan menunjukkan kandidat aplikasi yang ada untuk saat ini.

Tabel 1. Kandidat Aplikasi

\begin{tabular}{|l|l|}
\hline No & \multicolumn{1}{|c|}{ Aplikasi } \\
\hline 1 & Company Profile Website \\
\hline 2 & Tracking \\
\hline 3 & Penggajian \\
\hline 4 & Absensi \\
\hline
\end{tabular}

\section{A. Kolom What}

Kolom what menjelaskan mengenai data-data yang dibutuhkan oleh sistem informasi dari sudut pandang Planner, Owner, Designer, Builder, Sub-Contractor, User. Secara rinci data yang dibutuhkan dapat dilihat pada Tabel 3.

\section{B. Kolom How}

Kolom how berisi mengenai proses yang terjadi pada PT. Itewe Sarana Konstruksi berdasarkan sudut pandang Planner, Owner, Designer, Builder, Sub-Contractor, User. Daftar lengkap dari proses yang terjadi pada perusahaan dapat dilihat pada tabel 4 .

\section{Kolom Where}

Kolom where menjelaskan mengenai lokasi bisnis tempat sistem informasi berada dan juga konfigurasi beserta infrastruktur yang ada dari sudut pandang Planner, Owner, Designer, Builder, Sub-Contractor, User. Secara rinci lokasi yang dibutuhkan dapat dilihat pada Tabel 5.

\section{Kolom When}

Kolom when menjelaskan mengenai kegiatan dan kejadian beserta jadwal dari kegiatan tersebut dari sudut pandang Planner, Owner, Designer, Builder, Sub-Contractor, User. Secara rinci kegiatan dan jadwal yang dijelaskan dapat dilihat pada Tabel 6.

\section{E. Kolom Why}

Kolom why menjelaskan tujuan, motivasi dan batasan yang ditentukan dalam membangun sistem informasi yang diusulkan dengan berdasarkan sudut pandang Planner, Owner, Designer, Builder, Sub-Contractor, User. Secara rinci penjelasannya dapat dilihat pada Tabel 7. 


\section{HASIL DAN PEMBAHASAN}

Bagian ini akan membandingkan kondisi perusahaan saat ini dengan kondisi saat perusahaan sudah menerapkan aplikasi yang diusulkan.

\section{A. Value Chain Baru}

Sesudah menerapkan Zachman Framework, berikut ini merupakan hasil analisis value chain yang baru:

\section{1) Aktivitas utama}

a) Inbound Logistics, aktivitas ini tidak mengalami banyak perubahan dibandingkan dengan sebelumnya, yaitu perusahaan mengajukan permintaan serta membeli barang dari supplier, kemudian supplier akan mengirimkan barang tersebut sesuai dengan yang diminta oleh perusahaan.

b) Operations, aktivitas ini memiliki perbedaan dibandingkan dengan sebelumnya, dimana perbedaan tersebut adalah, perusahaan memasang GPS kepada kendaraan logistik.

c) Outbound Logistics, aktivitas ini memiliki perbedaan dibandingkan dengan sebelumnya, dimana perbedaannya terletak pada, jika sebelumnya perusahaan tidak dapat memantau secara langsung proses pengiriman barang yang ada, maka sekarang perusahaan dapat melakukan hal tersebut melaui aplikasi tracking yang diusulkan serta membuat laporan pengiriman barang tersebut.

d) Mareketing and Sales, aktivitas ini memiliki perbedaan dibangindkan dengan sebelumnya, yaitu dengan adanya company profile website, maka proses pemasaran yang dilakukan oleh perusahaan tidak bersifat koneksi ataupun perorangan karena dengan adanya company profile website, semua orang dapat mengakses website tersebut sehingga calon customer tidak terbatas hanya pada customer yang sudah dikenal. Terdapat pula fitur contact us pada website yang berguna untuk mempermudah calon customer yang ingin mengajukan pertanyaan mengenai produk yang ditawarkan oleh perusahaan. e) Services, aktivitas ini tidak memiliki perbedaan dengan yang sebelumnya.

\section{2) Aktivitas pendukung}

a) Firm Infrastructure, aktivitas ini memiliki perbedaan dibangindkan dengan sebelumnya, yaitu terdapat hardware SI/TI tambahan serta ruangan tempat penyimpanan server baru yang akan ditambahkan untuk mendukung sistem informasi yang disarankan.

b) Human Resources Management, aktivitas ini memiliki perbedaan dibangindkan dengan sebelumnya, yaitu dengan adanya aplikasi absensi, maka karyawan dapat melihat presensi mereka dan dapat melakukan pengajuan cuti melalui aplikasi absensi yang diusulkan. Selain itu, karyawan juga sekarang dapat melihat laporan dari penggajian mereka sendiri serta detail pemberian reward yang mereka terima dan jadwal THR yang mereka setiap tahunnya.

c) Technology Development, Aktivitas ini memiliki perbedaan dibangindkan dengan sebelumnya, dimana setelah sistem informasi yang diusulkan berjalan, maka aplikasi yang ada, hardware dan software serta jaringan yang dimiliki perusahaan akan masuk ke dalam aktivitas ini.

d) Procurement, aktivitas ini memiliki perbedaan dibangindkan dengan sebelumnya, yaitu dengan adanya sistem informasi yang diusulkan, maka perusahaan memerlukan beberapa peralatan tambahan seperti GPS yang ditempelkan ke kendaraan logistik serta beberapa hardware pendukung yang diperlukan untuk mendukung sistem informasi yang diusulkan.

\section{B. SWOT Baru}

Berikut merupakan hasil analisis SWOT baru setelah perusahaan menerapkan aplikasi yang diusulkan.

Tabel 2. Analisis SWOT Perusahaan

\begin{tabular}{|c|c|c|c|c|c|c|c|}
\hline Strengths & Bobot & Rating & Score & Weaknesses & Bobot & Rating & Score \\
\hline Memiliki dua gudang penyimpanan & 0.25 & 4 & 1,00 & $\begin{array}{l}\text { Perusahaan hanya menggunakan sedikit } \\
\text { bantuan dari SI/TI }\end{array}$ & 0,25 & 3 & 0,75 \\
\hline Bagian dari drup GIAS & 0,15 & 3 & 0,45 & $\begin{array}{l}\text { Penggunaan aplikasi hanya tiga buah, } \\
\text { yaitu Accurate, Microsoft Office }\end{array}$ & 0,15 & 2 & 0,30 \\
\hline Memiliki armada kendaraan sendiri & 0.30 & 3 & 0,90 & Belum terdapat divisi $I T$ & 0,20 & 1 & 0,20 \\
\hline $\begin{array}{l}\text { Memiliki pengalaman } \\
\text { distribusi bahan bangunan }\end{array}$ & 0.30 & 3 & 0,30 & $\begin{array}{l}\text { Pemasaran masih menggunakan metode } \\
\text { langsung, }\end{array}$ & 0,40 & 2 & 0,80 \\
\hline Jumlah & & & 2,65 & Jumlah & & & 2,05 \\
\hline Threats & Bobot & Rating & Score & Opportunities & Bobot & Rating & Score \\
\hline $\begin{array}{l}\text { Ketertinggalan jika tidak meman- } \\
\text { faatkan teknologi dengan maksimal }\end{array}$ & 0,40 & 3 & 1,20 & $\begin{array}{l}\text { Memiliki hubungan yang cukup baik } \\
\text { dengan } \text { customer dan supplier }\end{array}$ & 0,30 & 2 & 0,60 \\
\hline
\end{tabular}




\begin{tabular}{|l|l|l|l|l|l|l|}
\hline $\begin{array}{l}\text { Banyak perusahaan lain yang juga } \\
\text { bergerak dibidang bahan bangunan } \\
\text { dan konstruksi }\end{array}$ & 0,30 & 2 & 0,60 & $\begin{array}{l}\text { Tingginya angka pembangunan properti } \\
\text { di Indonesia }\end{array}$ & 0,45 & 2 \\
\hline $\begin{array}{l}\text { Terdapat kemungkinan customer tidak } \\
\text { membayar barang yang sudah dipesan }\end{array}$ & 0,30 & 2 & 0,60 & $\begin{array}{l}\text { Tingginya angka permintaan properti di } \\
\text { Indonesia }\end{array}$ & 0,25 & 2 \\
\hline Jumlah & & 2,00 & Jumlah & 0,50 \\
\hline
\end{tabular}

Tabel 3. Kolom What dari Sudut Pandang Zachman Framework

\begin{tabular}{|c|c|c|c|c|c|c|}
\hline Perspektif & Planner & Owner & Designer & Builder & Sub-Contractor & User \\
\hline What & $\begin{array}{lr}\text { Data yang } & \text { berkaitan } \\
\text { dengan } & \text { sistem } \\
\text { informasi } & \text { yang } \\
\text { disarankan: } & \\
\text {-Data akun } & \\
\text {-Data customer } \\
\text {-Data yang } & \text { dimiliki } \\
\text { perusahaan } & \end{array}$ & $\begin{array}{l}\text { Penggambaran relasi } \\
\text { antar tipe pengguna } \\
\text { dari sistem informasi } \\
\text { yang dibangun } \\
\text { dengan menggunakan } \\
\text { use case diagram }\end{array}$ & $\begin{array}{l}\text { Hasil } \\
\text { pemodelan } \\
\text { logika dalam } \\
\text { bentuk class } \\
\text { diagram }\end{array}$ & $\begin{array}{l}\text { Relasi antar } \\
\text { identifikasi data } \\
\text { yang dibutuhkan } \\
\text { untuk membangun } \\
\text { sistem informasi } \\
\text { usulan: } \\
\text { 1. Akun } \\
\text { 2. Customer } \\
\text { 3. Karyawan } \\
\text { 4. Driver } \\
\text { 5. Mobil Box } \\
\text { 6. Barang } \\
\text { 7. Gaji } \\
\text { 8. Absen }\end{array}$ & $\begin{array}{l}\text { Rancangan tabel dari } \\
\text { setiap entitas: } \\
\text { 1. Account } \\
\text { 2. Acc_type } \\
\text { 3. Post } \\
\text { 4. Contact_us } \\
\text { 5. Tracking } \\
\text { 6. Order } \\
\text { 7. Barang } \\
\text { 8. Mobil_box } \\
\text { 9. Driver } \\
\text { 10. Kinerja } \\
\text { 11. Karyawan } \\
\text { 12. Absen } \\
\text { 13. Cuti }\end{array}$ & $\begin{array}{l}\text { Berisi } \\
\text { penjelasan } \\
\text { detail dari setiap } \\
\text { data yang } \\
\text { dimasukkan ke } \\
\text { dalam tabel } \\
\text { database usulan }\end{array}$ \\
\hline
\end{tabular}

Tabel 4. Kolom Who dari Sudut Pandang Zachman Framework

\begin{tabular}{|c|c|c|c|c|c|c|}
\hline Perspektif & Planner & Owner & Designer & Builder & Sub-Contractor & User \\
\hline How & $\begin{array}{l}\text { Proses yang terjadi } \\
\text { pada sistem: } \\
\text { 1. Proses input } \\
\text { informasi } \\
\text { perusahaan } \\
\text { 2. Proses pengiri- } \\
\text { man barang } \\
\text { 3. Input data akun }\end{array}$ & $\begin{array}{l}\text { Penjelasan proses yang } \\
\text { terjadi: } \\
\text { 1. Proses input dan } \\
\text { penyebaran } \\
\text { informasi } \\
\text { 2. Proses input data } \\
\text { driver dan mobil } \\
\text { box }\end{array}$ & $\begin{array}{l}\text { Penggambaran } \\
\text { proses dengan } \\
\text { menggunakan } \\
\text { activity diagram }\end{array}$ & $\begin{array}{l}\text { Penggambaran } \\
\text { proses interaksi antar } \\
\text { objek dengan } \\
\text { menggunakan } \\
\text { sequence diagram }\end{array}$ & $\begin{array}{l}\text { Flowchart dari } \\
\text { cara } \\
\text { penggunaan } \\
\text { aplikasi }\end{array}$ & $\begin{array}{l}\text { Bentuk laporan } \\
\text { yang dihasilkan } \\
\text { dari aplikasi } \\
\text { yang diusulkan }\end{array}$ \\
\hline
\end{tabular}

Tabel 5. Kolom Where dari Sudut Pandang Zachman Framework

\begin{tabular}{|c|c|c|c|c|c|c|}
\hline Perspektif & Planner & Owner & Designer & Builder & Sub-Contractor & User \\
\hline Where & $\begin{array}{l}\text { Tempat sistem } \\
\text { berada yaitu pada } \\
\text { bangunan ruko dari } \\
\text { PT. Itewe Sarana } \\
\text { Konstruksi }\end{array}$ & $\begin{array}{l}\text { Peta jaringan } \\
\text { saat ini }\end{array}$ & $\begin{array}{l}\text { Peta } \\
\text { jaringan } \\
\text { usulan }\end{array}$ & $\begin{array}{l}\text { Tempat ruangan } \\
\text { dimana sistem } \\
\text { informasi usulan } \\
\text { akan diletakkan }\end{array}$ & \begin{tabular}{lr}
\multicolumn{2}{l}{ Konfigurasi } \\
dari jaringan \\
yang akan \\
digunakan pada \\
sistem \\
informasi \\
usulan
\end{tabular} & $\begin{array}{l}\text { Spesifikasi perangkat keras } \\
\text { yang dibutuhkan: } \\
\text { 1. PC: I3-9100F, RAM 4GB, } \\
\text { SSD 240GB Motherboard } \\
\text { H310M PSU } 300 \text { Watt } \\
\text { 2. Server: Processor Xeon E- } \\
\text { 2104G, RAM 8GB, HDD } \\
\text { 1TB PSU 500 Watt }\end{array}$ \\
\hline
\end{tabular}

Tabel 6. Kolom Who dari Sudut Pandang Zachman Framework

\begin{tabular}{|c|c|c|c|c|c|c|}
\hline Perspektif & Planner & Owner & Designer & Builder & Sub-Contractor & User \\
\hline Who & $\begin{array}{lr}\text { Pihak-pihak } & \text { yang } \\
\text { memiliki } & \text { peran } \\
\text { dalam menggunakan } \\
\text { aplikasi } & \text { yang } \\
\text { diusulkan } & \end{array}$ & $\begin{array}{l}\text { Pihak yang akan } \\
\text { mengurus aplikasi } \\
\text { yang diusulkan: } \\
\text { 1. IT planning and } \\
\text { strategy } \\
\text { 2. IT application and } \\
\text { development } \\
\text { 3. IT operation }\end{array}$ & 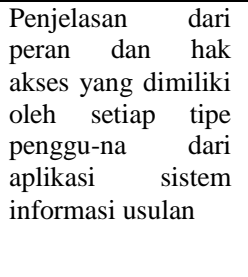 & $\begin{array}{lr}\text { Berisi gambaran } \\
\text { dari tampilan atau } \\
\text { interface dari setiap } \\
\text { aplikasi r yang } \\
\text { diusulkan }\end{array}$ & $\begin{array}{l}\text { Hak akses ddari } \\
\text { hal-hal yang } \\
\text { dapat dilihat } \\
\text { oleh setiap tipe } \\
\text { akun pengguna } \\
\text { dari sistem } \\
\text { informasi } \\
\text { usulan }\end{array}$ & $\begin{array}{l}\text { Penjelasan } \\
\text { mengenai } \\
\text { penguna dari } \\
\text { aplikasi yang } \\
\text { diusulkan }\end{array}$ \\
\hline
\end{tabular}


Tabel 7. Kolom When dari Sudut Pandang Zachman Framework

\begin{tabular}{|c|c|c|c|c|c|c|c|c|c|c|c|c|c|c|}
\hline Perspektif & \multicolumn{14}{|c|}{ When } \\
\hline Planner & \multicolumn{14}{|c|}{ Menjelaskan aktivitas yang memiliki hubungan degan proses pada sistem informasi } \\
\hline Owner & \multicolumn{14}{|c|}{$\begin{array}{l}\text { Menjelaskan menjelaskan gambaran dari tahap-tahap pengembangan proyek sistem informasi yang disarankan dari sudut } \\
\text { pandang manajemen }\end{array}$} \\
\hline \multirow[t]{7}{*}{ Designer } & \multirow{2}{*}{\multicolumn{7}{|c|}{ 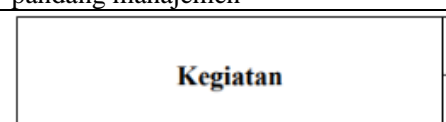 }} & \multicolumn{6}{|c|}{ Bulan ke-3 } & \\
\hline & & & & & & & & \multicolumn{2}{|l|}{1} & \multicolumn{2}{|c|}{2} & 3 & 4 & \\
\hline & \multicolumn{6}{|c|}{ 1. Menentukan Entitas } & & & & & & & & \\
\hline & \multicolumn{6}{|c|}{ 2. Merancang Use Case Diagram } & & & & & & & & \\
\hline & \multicolumn{6}{|c|}{ 3. Merancang Database } & & & & & & & & \\
\hline & \multicolumn{6}{|c|}{ 4. Merancang Diagram } & & & & & & & & \\
\hline & \multicolumn{6}{|c|}{ 5. Merancang Interface } & & & & & & & & \\
\hline \multirow[t]{6}{*}{ Builder } & \multirow[t]{2}{*}{ Event } & \multicolumn{4}{|c|}{ Bulan 4} & & & & & \multicolumn{3}{|c|}{ Bulan 6} & & \\
\hline & & 1 & 2 & 3 & 4 & 1 & 2 & 3 & 4 & 1 & 2 & 4 & & \\
\hline & Coding & & & & & & & & & & & & & \\
\hline & $\begin{array}{l}\text { Membuat basis } \\
\text { data }\end{array}$ & & & & & & & & & & & & & \\
\hline & Front-end coding & & & & & & & & & & & & & \\
\hline & Back-end coding & & & & & & & & & & & & & \\
\hline Sub-Contractor & \multicolumn{14}{|c|}{ Menjelaskan perkiraan waktu yang dibutuhkan untuk melakukan proses coding aplikasi yang diusulkan } \\
\hline User & \multicolumn{14}{|c|}{ Menjelaskan total keseluruhan waktu yang dibutuhkan memalui full gantt chart } \\
\hline
\end{tabular}

Tabel 8. Kolom Why dari Sudut Pandang Zachman Framework

\begin{tabular}{|c|c|c|c|c|c|c|}
\hline Perspektif & Planner & Owner & Designer & Builder & Sub-Contractor & User \\
\hline Why & $\begin{array}{l}\text { Menjelaskan visi dan } \\
\text { misi perusahaan } \\
\text { 1. Visi: Menjadi } \\
\text { perusahaan pilih- } \\
\text { an pelaku bidang } \\
\text { konstruksi } \\
\text { 2. Misi: Menyedia- } \\
\text { kan dan berinova- } \\
\text { si dalam mengem- } \\
\text { bangangkan pro- } \\
\text { duk dan sistem } \\
\text { konstruksi }\end{array}$ & $\begin{array}{l}\text { Menjelaskan } \\
\text { tujuan dari } \\
\text { perancangan } \\
\text { sistem informasi } \\
\text { yang baru }\end{array}$ & $\begin{array}{l}\text { Menjelaskan } \\
\text { batasan dalam } \\
\text { proses perancang- } \\
\text { an sistem: } \\
\text { 1. Batasan tipe } \\
\text { akun dan nilai } \\
\text { atribut } \\
\text { 2. Hak akses dari } \\
\text { tiap-tiap tipe } \\
\text { akun }\end{array}$ & $\begin{array}{l}\text { Aturan dalam } \\
\text { perancang-an sistem } \\
\text { informasi usulan: } \\
\text { 1. Menggunakan } \\
\text { visual studio 2019, } \\
\text { Visual Studio Code, } \\
\text { X-Code dan Androd } \\
\text { Studio } \\
\text { 2. Bahasa } \\
\text { pemrograman } \\
\text { VB.NET dan PHP, } \\
\text { CSS dan JavaScript }\end{array}$ & $\begin{array}{l}\text { Aturan pada } \\
\text { aplikasi usulan: } \\
\text { 1. Script bebas } \\
\text { dari ancaman } \\
\text { 2. Laporan error } \\
\text { mudah dipahami } \\
\text { 3. Wajib terdapat } \\
\text { pop-up message } \\
\text { 4. Logout otomatis }\end{array}$ & $\begin{array}{l}\text { Menjelasakan } \\
\text { mengenai SOP } \\
\text { dari setiap } \\
\text { aplikasi yang } \\
\text { diusulkan }\end{array}$ \\
\hline
\end{tabular}

Tabel 9. Tabel SWOT Baru

\begin{tabular}{|c|c|c|c|c|c|c|c|}
\hline Strengths & Bobot & Rating & Score & Weaknesses & Bobot & Rating & Score \\
\hline $\begin{array}{lll}\text { Memiliki } & \text { dua } & \text { gudang } \\
\text { penyimpanan } & & \end{array}$ & 0,20 & 4 & 0,80 & $\begin{array}{l}\text { Memerlukan koneksi } \text { internet } \\
\text { untuk menggunakan aplikasi } \\
\text { yang baru }\end{array}$ & 0,70 & 1 & 0,70 \\
\hline Bagian dari drup GIAS & 0,10 & 3 & 0,30 & \multirow{5}{*}{$\begin{array}{l}\text { Karyawan yang belum ahli } \\
\text { dalam menggunakan aplikasi } \\
\text { yang baru }\end{array}$} & \multirow[t]{5}{*}{0,30} & \multirow[t]{5}{*}{2} & \multirow[t]{5}{*}{0,60} \\
\hline $\begin{array}{l}\text { Memiliki armada kendaraan } \\
\text { sendiri }\end{array}$ & 0,10 & 3 & 0,30 & & & & \\
\hline $\begin{array}{l}\text { Memiliki pengalaman dalam } \\
\text { distribusi bahan bangunan }\end{array}$ & 0,20 & 3 & 0,60 & & & & \\
\hline $\begin{array}{l}\text { Pengawasan terhadap pengiriman } \\
\text { barang dapat dilakukan dengan } \\
\text { baik, sehingga minim } \\
\text { kemungkinan barang hilang di } \\
\text { perjalanan }\end{array}$ & 0,20 & 4 & 0,80 & & & & \\
\hline $\begin{array}{l}\text { Memanfaatkan bantuan teknologi } \\
\text { informasi dalam membantu } \\
\text { proses bisnis perusahaan }\end{array}$ & 0,20 & 4 & 0,80 & & & & \\
\hline \multicolumn{3}{|l|}{ Jumlah } & 3,60 & \multicolumn{3}{|l|}{ Jumlah } & 1,30 \\
\hline Threats & Bobot & Rating & Score & Weaknesses & Bobot & Rating & Score \\
\hline $\begin{array}{l}\text { Banyak perusahaan lain yang } \\
\text { juga bergerak di bidang bahan }\end{array}$ & 0,20 & 4 & 0,80 & $\begin{array}{l}\text { Memerlukan koneksi } \\
\text { untuk menggunakan }\end{array}$ & 0,70 & 1 & 0,70 \\
\hline
\end{tabular}




\begin{tabular}{|c|c|c|c|c|c|c|c|}
\hline bangunan dan konstruksi & & & & yang baru & & & \\
\hline \multirow{3}{*}{$\begin{array}{l}\text { Terdapat kemungkinan customer } \\
\text { tidak membayar barang yang } \\
\text { sudah diterima sesuai dengan } \\
\text { ketentuan pembayaran yang } \\
\text { sudah disepakati }\end{array}$} & \multirow[t]{3}{*}{0,20} & \multirow[t]{3}{*}{1} & \multirow[t]{3}{*}{0,20} & $\begin{array}{l}\text { Tingginya angka pembangunan } \\
\text { properti di Indonesia }\end{array}$ & 0,30 & 3 & 0,90 \\
\hline & & & & $\begin{array}{l}\text { Tingginya angka permintaan } \\
\text { properti di Indonesia }\end{array}$ & 0,20 & 2 & 0,40 \\
\hline & & & & $\begin{array}{l}\text { Dapat menjangkau pasar yang } \\
\text { lebih luas dengan adanya } \\
\text { company profile website }\end{array}$ & 0,30 & 3 & 0,90 \\
\hline \multicolumn{3}{|l|}{ Jumlah } & 1,80 & \multicolumn{3}{|l|}{ Jumlah } & 2,80 \\
\hline
\end{tabular}

\section{Perbandingan Skor SWOT}

Tabel 10. Perbandingan Skor SWOT

\begin{tabular}{|l|l|l|}
\hline SWOT & $\begin{array}{l}\text { Jumlah Skor } \\
\text { Lama }\end{array}$ & $\begin{array}{l}\text { Jumlah Skor } \\
\text { Baru }\end{array}$ \\
\hline Strengths & 2,65 & 3,60 \\
\hline Weaknesses & 2,05 & 1,30 \\
\hline Opportunities & 2,40 & 2,80 \\
\hline Threats & 2,00 & 1,80 \\
\hline
\end{tabular}

Tabel 10 menunjukkan perbandingan dari skor analisis SWOT pada kondisi perusahaan saat ini dengan saat kondisi saat perusahaan sudah menerapkan sistem informasi yang disarankan. Dari tabel ini dapat dilihat bahwa ada kenaikan di skor Strengths dan Opportunities serta pengurangan pada Weakness dan Threats, sehingga perusahaan bisa semakin meningkatkan langkah-langkah sejalan strategi SO.

\section{Arsitektur Aplikasi}

Bagian ini akan menjelaskan mengenai perbandingan antara arsitektur aplikasi perusahaan sebelumnya dengan yang baru. Tabel 11 menjelaskan arsitektur aplikasi yang lama dengan yang baru, yaitu terdapat tiga jenis aplikasi yang ada, yaitu aplikasi yang dipertahankan (retain), aplikasi yang digantikan (replaced) dan aplikasi yang baru (penambahan). Terdapat satu aplikasi yang dipertahankan, yaitu Accurate. Kemudian terdapat satu aplikasi yang digantikan yaitu company profile website dan terdapat tiga aplikasi baru, yaitu tracking, penggajian dan absensi.

Tabel 11. Arsitektur Aplikasi

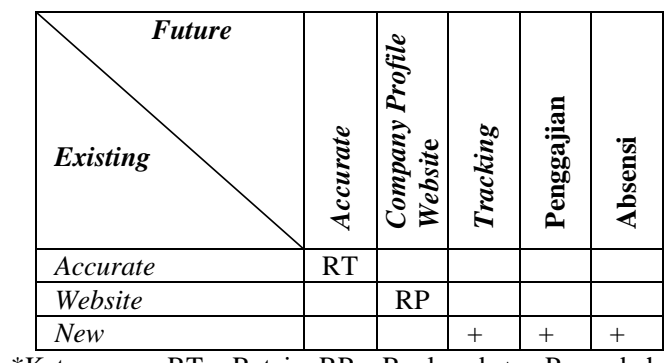

*Keterangan: $\mathrm{RT}=$ Retain, $\mathrm{RP}=$ Replaced,$+=$ Penambahan

\section{E. Portofolio Aplikasi}

Bagian ini akan menjelaskan mengenai hasil dari analisis portofolio dari aplikasi-aplikasi yang diusulkan. Berikut merupakan tabel yang akan menunjukkan hasil dari portofolio aplikasi tersebut.

Tabel 12. Portofolio Aplikasi

\begin{tabular}{|l|l|}
\hline Strategic & High Potential \\
\hline Tracking & Company Profile Website \\
\hline Accurate & $\begin{array}{l}\text { Aplikasi Penggajian } \\
\text { Aplikasi Abensi }\end{array}$ \\
\hline Key Operational & Support \\
\hline
\end{tabular}

Tabel 12 menunjukkan hasil analisis portofolio aplikasi yang diusulkan kepada perusahaan. Adapun penjelasan dari masing-masing aplikasi pada tabel tersebut adalah:

1. Strategic, merupakan aplikasi yang penting untuk keberlangsungan strategi bisnis pada masa yang akan datang. Aplikasi company profile website termasuk dalam aplikasi ini.

2. Key Operational, merupakan aplikasi yang digunakan oleh perusahaan untuk melakukan kegiatan operasional mereka saat ini. Aplikasi Accurate termasuk dalam aplikasi ini.

3. High Potential, merupakan aplikasi yang memiliki potensi penting untuk mencapai kesuksesan pada masa depan. Aplikasi Tracking termasuk ke dalam aplikasi ini.

4. Support, merupakan aplikasi yang berguna untuk pendukung tapi tidak bersifat vital bagi kesuksesan. Aplikasi penggajian dan aplikasi absensi termasuk ke dalam aplikasi ini.

\section{KESIMPULAN}

Berdasarkan seluruh data yang terdapat pada laporan ini, maka kesimpulan yang dapat diambil adalah sebagai berikut:

1. Berdasarkan analisis terhadap proses bisnis perusahaan pada saat ini dengan menggunakan SWOT dan value chain, maka dapat disarankan empat buah aplikasi, yaitu company profile website, tracking, penggajian dan absensi.

2. Berdasarkan hasil perancangan enterprise architecture dengan menggunakan framework Zachman, maka dapat diketahui bahwa hasil model rancangan terbagi menjadi enam buah sudut pandang yang terdiri dari Planner, Owner, Designer, Builder, Sub-Contractor dan User dengan kombinasi baris yang terdiri dari $5 \mathrm{~W}+1 \mathrm{H}$. Perancangan aplikasi yang ada dilakukan dengan berdasarkan dari analisis SWOT, value chain dan visi 
misi perusahaan agar dapat selaras dengan kebutuhan yang ada.

3. Kenaikan di skor Strengths dan Opportunities serta pengurangan pada Weakness dan Threats pada perbandingan Analisis SWOT yang lama dan baru membuat perusahaan bisa semakin meningkatkan langkah-langkah sejalan strategi SO dengan adanya arsitektur enterprise yang disusun menggunakan Zachman Framework.

\section{REFERENSI}

[1] K. Kasemin, Agresi Perkembangan Teknologi Informasi. Jakarta: Prenamedia Group, 2015.

[2] A. Sudirman et al., Sistem Informasi Manajemen. Yayasan Kita Menulis, 2020.

[3] Febrianty et al., Manajemen Perubahan Perusahaan di Era Transformasi Digital. Yayasan Kita Menulis, 2020.

[4] R. A. Purba et al., Aplikasi Teknologi Informasi: Teori \& Implementasi. Yayasan Kita Menulis, 2020.

[5] H. Z. Asikin and W. P. Suhartana, Pengantar Hukum Perusahaan. Jakarta: PRENAMEDIA GROUP, 2016.

[6] A. Sutedi, Buku Pintar Hukum Perseroan Terbatas. Jakarta: Raih Asa Sukses, 2015.

[7] M. N. Soleh, Manajemen Rantai Pasok Konstruksi. Yogyakarta: Penerbit Pustaka Pranala, 2020.

[8] Bagaskoro, Pengantar Teknologi Informatika dan Komunikasi Data. Yogyakarta: Penerbit Deepublish, 2019.

[9] F. Sulianta, Strategi Merancang Arsitektur Sistem Informasi Masa Kini. Jakarta: PT Elex Media Komputindo, 2019.

[10] Romindo et al., Sistem Informasi Bisnis. Jakarta: Yayasan Kita Menulis, 2020.

[11] R. Setiawan, "Perancangan Arsitektur Enterprise Untuk Perguruan Tinggi Swasta Menggunakan Togaf Adm," J. Algoritm., vol. 12, no. 2, pp. 548-561, 2015, doi: 10.33364/algoritma/v.12-2.548.

[12] R. Pramudita and N. Safitri, "Integrasi Zachman Framework dan TOGAF ADM ( Architecture Development Method )," Inf. Syst. Educ. Prof., vol. 1, no. 2, pp. 157-166, 2016. 